\title{
The Role of Council Committees in Promoting Financial
}

\section{Accountability}

\author{
Fundiswa T Khaile ${ }^{1}$, Gregory J Davids ${ }^{1}$ \\ ${ }^{1}$ School of Government, Faculty of Economic and Management Sciences, University of the Western Cape, \\ Private Bag X17, Bellville, \\ *Contact author: fkhaile@uwc.ac.za
}

\begin{abstract}
Financial accountability in municipalities is a critical aspect of municipal fiscal governance. It constitutes one of the fundamental roles exercised by the municipal council to ensure effective and efficient utilization of financial resources. Non-executive councilors organised through council committees are expected to shoulder the responsibility of exercising financial accountability. The Audit Committee is one of the committees established by municipal council to assist in holding the executive accountable for the manner in which municipal financial resources are managed. These committees are created through various legislative regimes and municipal council Rules of Order. The oversight committees had different outcomes with regard to financial accountability in different municipalities. The results of this research suggest that these committees they have not been very effective in exercising their responsibilities. The factors that contribute to accountability, transparency and regularity to ensure the effective functioning of these committees were explored. Therefore, the following research question was posed to guide this research.
\end{abstract}

1. What are the major underlying causes that contribute to financial accountability at the local level?

2. What are the strengths and weaknesses of council committees and how they could contribute towards the strengthening of financial accountability?

The Stellenbosch Municipality was used as a case study to explore the role of council committees in exercising financial accountability. The research findings revealed that there is need to establish a culture of openness, transparency and accountability. Equally, the council committees must be empowered with the necessary authority and capacity to enable them to discharge their accountability function.

Key Words: Municipal Council Committees, Financial accountability, Legislative Authority, Executive Authority, Budget process and Municipal Administration.

DOI: $10.7176 / \mathrm{PPAR} / 10-8-08$

Publication date:August $31^{\text {st }} 2020$

\section{Introduction}

Local government undeniably has an important role to fulfill in the democratic system that emerged in postapartheid South Africa. South Africa's municipal councils are seen as cornerstones of local democracy and legitimacy. As local elected assemblies, municipal councils are key structures endowed with the law making, representation and financial accountability powers and functions in terms of section 151 of the Constitution of Republic of South Africa(RSA), 1996 (Act 108 of 1996). The combination of these functions position municipal councils to play a critical role in ensuring accountability of the executive and bureaucratic structures of the municipality. The municipal council's authority to exercise financial accountability is of immense importance considering the limited financial resources in municipalities. Municipal council legislative oversight had been delegated to section 79 Portfolio Committees. Section 79 Portfolio Committees are established in terms of Municipal Structures Act of 1998 (Act 117 of 1998) to act on behalf of the council. The number of portfolio committees varies within municipalities and is chaired by the political head. The committees comprise of politicians and administrators. The delegated responsibilities of these sections 79 Portfolio Committees are to ensure administrative accountability for the implementation of council policy (Local Government: Municipal Structures Act of 1998 (Act 117 of 1998). As a result of the intense criticism directed at local government for failing to deliver on its Constitutional mandate, a necessity arise for in-depth study to evaluate the role of municipal 
council committees in ensuring policy implementation and accountability. Similarly, there is a need to identify and develop an understanding of the factors that negate the effectiveness of these council committees.

\section{Literature Review on Accountability and Financial Accountability}

Accountability and financial accountability has become a critical part of public governance. As a concept that originally emerged as an element of public finance management (i.e. "computing and giving account for the expenditure of public funds Redlynch (2001:15), the concept of accountability now goes beyond the domain of public finance and applies to a wide array of important decisions and authorities that are responsible for making those decisions. At the centre of the concept of accountability is the checking and balancing of potential abuse of power by public officials with the objective of limiting the potential for corruption of public offices and officials. The domain of accountability has, however, expanded, through time, from the proper exercising of power to include accountability for improving the efficiency and reducing waste in carrying out public programme. It also expanded, as of late, "to focus on the effectiveness of government in meeting publicly desired outcomes for programme and operations" (Community Law Centre: 2008).

Griffith (2005: 10) argues that accountability is acknowledged to be 'a notoriously imprecise term. The relevant academic literature typically spends some time explaining both what it is and what it is not. As to what is, as good a starting point as any is the approach adopted in the 2001 Sharman Report, Holding to Account: The review of Audit and Accountability for Central Government. It divides the notion of accountability into four aspects:

- giving an explanation - through which the main stakeholders (for example Parliament) are advised about what is happening, perhaps through an annual report, outlined performance and capacity;

- providing further information when required - where those accountable may be asked to account further, perhaps by providing information (e.g. to a select committee) on performance, beyond accounts already given;

- reviewing, and if necessary revising - where those accountable respond by examining performance, systems or practices, and if necessary, making changes to meet expectations; and

- granting redress or imposing sanctions - if mechanism to impose sanctions exists, stakeholders might enforce their rights on those accountable to effect changes.

Accountability, according to Dye and Stephenhurst (1997:12) "is a process that subjects a form of control over departments and agencies, causing them to give a general accounting for their actions. "

\section{Legislative Committees}

Legislatures of modern democracies are complex institutions entrusted with huge responsibilities. The role of legislatures had grown substantially along that of government as a whole. Mattsson \& Strom (1995:249) agree that legislatures have become "large and unwielding bodies "with variety of functions and responsibilities. The nature and the amount of work performed by the legislature in terms of analysing, deliberating, and approving volumes of documents can be daunting for legislators. Legislative committees are widely regarded as sub-groups or sub-division of the assembly or legislature. Wehner (2003:29) states that committees are small groups of legislators who are delegated, "on either a temporary or permanent basis" the responsibility to investigate issues in detail and propose policy changes. Many of the activities of the legislature do not take place in the plenary Mattsson \& Strom (1995:249). Accordingly, committees of the legislature are established to assist in transacting some of the business of the legislature. Davidson \& Olleszek (1996:53) argue that committees are the "means through which legislatures shift through an otherwise impossible jumble of bills, proposal and issues". Legislative committees are established for a variety of reasons which include institutional tasks such as law making, budgeting and administrative oversight.

In addition to institutional tasks, legislatures establish committees to attend to "household" issues" (Mattson \& Strom, 1995:257). Specifically, committees are established for legislative purpose, financial purpose, investigative purpose and housekeeping purpose.

It can be argued that the existence of committees is recognition that the legislature is often ill-prepared to engage in any meaningful detail its law-making, representation and oversight functions. Mattsson \& Strom (1995:249) 
supports this argument when saying that legislative committees promote efficiency and productivity emanating from specialisation of committees and adequate time for committees to deliberate on issues.

The significance attached to legislative committees is reflected in how they are regarded globally. For example, in South Africa legislative committee are referred to as engine rooms, while in other countries such as Bangladesh, they are depicted as "miniature legislatures or microcosms of their parent bodies" (Strom, 1998:96). Equally, President Woodrow Wilson is quoted by Huitt (1954: 340) as having described committees as "the very heart of law making process in the United States and that Congressional committee is Congress at work". The legislative committee is also recognised by Rabrenovic (2009:75) as a key financial instrument of the legislature to exercise financial accountability. According to him, these committees are useful in examining the conformity of the executive to issues of "regularity, propriety and value for money".

\section{Factors Impacting on Legislative Committees effectiveness to Exercise Financial Accountability}

It has been highlighted that effective financial accountability by legislatures require the creation of appropriate mechanisms. However, the existence of these mechanisms does not necessarily guarantee effective financial accountability. It is important that these mechanisms must be complemented by other factors to promote a culture of governance that facilitates a conducive environment within which legislatures can exercise accountability in general and financial accountability in particular.

Ogul in Lees (1977:196) state, there are "opportunity factors that produce an oversight-maximising syndrome". According to Lees, factors like "legal authority, staff resources, committee structure, status of committee and cooperative relations with executive structures" have the ability to promote effective financial accountability.

Similarly, in his articulation of the conceptual framework of legislative committees, Mahiuddin (2009:13) argues that the effectiveness of committees to perform their functions is dependent on the appropriate "political environment, committee structure and committee capacity". Political environment refers to issues such as the political situation, nature of political parties and society. The committee structure on the other hand speaks to the authority, types and the establishment processes of committees. Committee capacity entails technical, financial and human resources at the disposal of the committees to carry out its responsibilities.

Following Ogul and Mahiuddin's above propositions, the factors that impact on the effectiveness of the legislative committees can be summarised as their structure, powers and procedures. According to Mattson \& Strom $(1995: 250)$ structures, procedures and powers of committees "impact the ways in which they foster or hinder the legislative effectiveness for financial accountability.

\section{Powers of Committees}

In general, legislative committees are vested with powers to scrutinise proposed legislation as well as conducting oversight. According to Mahiuddin (2009:22) constitutionally established committees are generally accompanied by prescriptions on establishment as well as their jurisdiction. He adds that the constitution prescribes for broad principles of issues such as "information acquisition", the right to call members of the executive and the right to demand access to information.

The power or authority of committees is defined by their respective parent legislatures. In some instances, committees such as those dealing with financial matters are vested with the authority to "examine whether public money voted by the legislature has been spent in accordance with the legislative intentions and with due regard to issues of regularity, propriety and value for money" (Schick, 1999:30).

According to Wehner (2003:29)) committees generally perform the following functions:

I. "to advice the legislature after undertaking an inquiry or after members negotiate with each other;

II. to inquire and advice;

III. to scrutinise and control, seeing whether and how a process is being performed. 


\section{Committees Procedures}

According to Wehner (2003:29) the manner in which legislative committees perform their functions is greatly influenced and governed by the nature of the "institution of which they form part". Accordingly, committees are expected to function in a non-partisan manner. Similarly, the effectiveness of the committees is dependent on how independent it is from the ruling majority party in the legislature. The independence and impartiality of the committees, especially finance committees such as the Public Accounts Committees is achieved through legal and traditional legislative practices. One such prescription is that the chairperson of the committee must be a member of the opposition party (Rabrenovic, 2009:76).

The committee, especially the Public Accounts Committee uses measure such as the Auditor-General's report and other special reports to summon, investigate, and engage through a hearing the elected representatives and officials. Similarly, the committee has the authority to make recommendation and may impose sanctions (Rabrenovic, 2009:77).

Legislative committees responsible for ensuring effective financial accountability must have a deliberate focus on and interest in exercising substantive scrutiny over the financial affairs of government departments.

To ensure effective oversight, committee members must be familiar with the role and understanding the budget process and content. Similarly, Rabrenovic (2009:217) suggests that members represented in committees must have the capacity to participate in the budget and finance hearings.

Rabrenovic (2009:217) proposes the following as requirements for legislative committees responsible for ensuring financial accountability:

I. There is a need to for establishing a special legislative committee that deals solely with financial accountability. According to Rabrenovic (2009:217) this will require changes of rules of procedure of the respective chamber.

II. The committee members must be "extensively trained to in order to obtain the knowledge necessary to provide support to the legislature in exercising financial accountability.

The main aim of this committee should be to "enhance the oversight role by the legislature. Specifically, the focus of the committee should be to exercise vigorous scrutiny of the public expenditure continuously during the financial year (Wehner, 1955:3).

III. The committees should be composed in a manner that promotes equitable representation of political parties in the legislature. However, an attempt must be made to minimise the political polarisation of the committees. Therefore, constructive cooperation among members represented in the committee must be encouraged.

IV. Rabrenovic (2009:218) is of the view that appointing a member of the opposition to chair the committee promotes robustness and independence of the committee.

V. The committee must have the power to summon or call any person to testify before it. Similarly, the committee must have the authority to access relevant information from any person or government institution. 


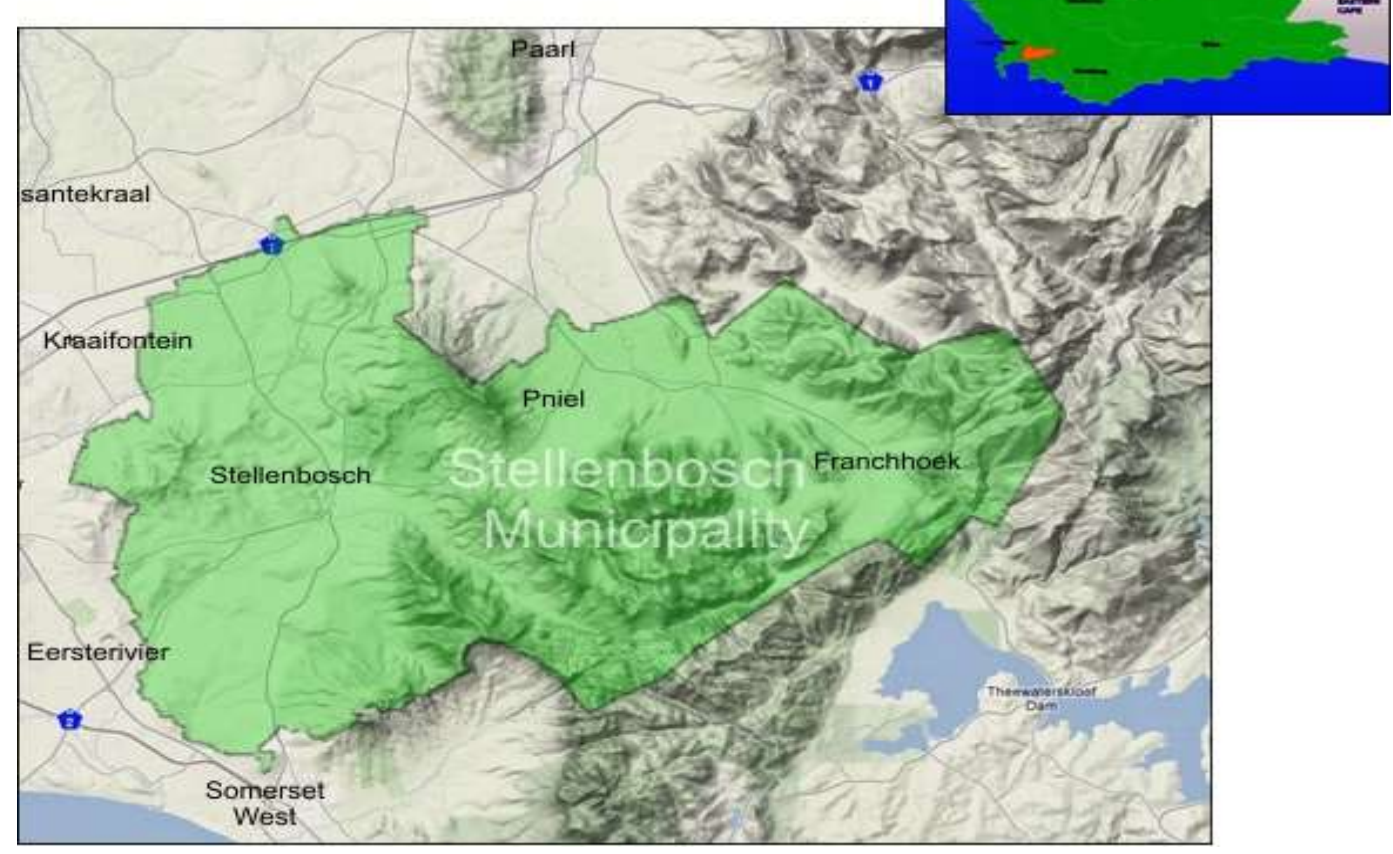

Figure 1: Man of Stellenbosch Municipalitv

The Stellenbosch Municipality was established in terms of section 9 and16 of the Municipal Structures Act (117 of 1998) which provides for the MEC of the Local government to amend the section 12 notice. In terms of the "Stellenbosch Municipality fourth establishment Amendment Notice as published in the Western Cape Provincial Gazette Extraordinary No. 6137 dated 8 June 2004" the Stellenbosch Municipality has 37 councillors. Of these nineteen (19) are ward councillors and eighteen (18) are proportionally elected councillors. Stellenbosch Municipality is a category B municipality with a mayoral executive system. The Stellenbosch Municipality's Annual Report 2009/10, party representation in the municipal council is as follows (see figure 2).

Figure 2: Municipal Council Party Representation

\begin{tabular}{|l|l|}
\hline Political Party & No. of Councillors \\
\hline African National Congress & 17 \\
\hline Democratic Alliance & 14 \\
\hline African Christian Democratic Party & 2 \\
\hline Independent & 1 \\
\hline Independent Democrats & 1 \\
\hline Kayamandi Community Association & 1 \\
\hline United Democratic Movement & 1 \\
\hline Total & 37 \\
\hline
\end{tabular}

Source: Annual Report 2009/10 


\section{Municipal Council}

The municipal council of Stellenbosch Municipality is the primary structure with the mayoral executive system of the municipality. Like other legislatures, the municipal council is the legitimate representative of the citizens of Stellenbosch Municipality and has legislative and executive powers. As with other legislatures in South Africa, the legislative powers of the Stellenbosch municipality are vested in the council (section 151 of the Constitution of the RSA, 1996). In terms of this provision, the municipal council has the constitutional authority to pass laws as well as ensure that the laws are implemented in accordance with the councils' intent.

Therefore, councillors in Stellenbosch municipality have a critical role to play to ensure that the Executive Mayor, Mayoral Committee and the municipal administration adhere to the agenda set by the council through the approved Integrated Development Plans (IDP), budget and other council resolutions in general. The Stellenbosch Municipality has through its Rules of Order, adopted various mechanisms to enable its exercise it functions and responsibilities effectively Stellenbosch Rules of Order (2006:29). For purpose of financial oversight to ensure accountability, the municipal council has established the Oversight Committees, Steering Committee and Audit Committee to fulfill this role. These committees are an extension of and reports to the municipal council.

\section{Council Committees Exercising Financial Accountability in the Stellenbosch Municipality}

The municipal council of Stellenbosch Municipality has established two committees to assist it to exercise financial accountability. Specifically, two council committees, namely, audit and oversight committees were established to assist the municipal council in exercising financial accountability between the period of 2006 to 2010 .

\section{Audit Committee}

An audit committee is one of the finance related committee established to provide the municipal council with the necessary specialised support to exercise financial accountability.

Unlike the other council committees which are not compulsory, the audit committee is a statutory requirement in terms of section 166(1) of the MFMA. The Stellenbosch Municipality established audit committee in terms of the act and it comprises of four members. The members are independent professionals recruited from outside the municipality. The audit committee is appointed by the municipal council. Political representatives are excluded from the audit committee. The committee is structured in a manner that would enable it to be an independent advisory body for the municipal council. In addition, the committee provides the municipal council with finance management information from an external perspective. Consequently, the audit committee provides the councillors and the council in general with the relevant information to utilise in their exercise of financial accountability function.

\section{Some of the functions of the audit committee include:}

I. Advice the municipality and its constituent structures on all financial matters;

II. Review the annual statement in order to provide the municipal council with an authoritative, informed and credible advice of the financial position of the municipality;

III. Provide the municipal council with information regarding the compliance with the laws such as Municipal Finance Management Act, the Division of Revenue Act and other applicable regulations.

IV. Assist the council to respond to issues raised by the Auditor-General as well conduct financial investigations as and when requested by the municipal council.

\section{Oversight Committees}

The municipal council established an oversight committee as provided for by section 79 of the Municipal Structures Act 117 of 1998 . Unlike the audit committee which is established in terms of statutory requirement, the oversight committee is established in terms of rule of order. The oversight committee was established in terms of Stellenbosch Municipality's Part 12 of the Rules of Order of 2006 which provides for the "establishment, composition procedures powers and functions of committee". Non-executive councillors serve on the oversight committee. However, it is not clear whether the council has delegate powers to the oversight committee. However, the councillors interviewed indicated that municipal council expects the oversight committees to consider the annual report. The annual report is a requirement placed on all municipalities and municipal entities as a key reporting instrument for municipalities to report against performance targets outlined in their strategic plans (Section 71 of the Municipal Finance Management Act, 56 of 2003). In considering the annual report, the oversight 
committee must exercise a detailed analysis and review produce the oversight report. This oversight report is presented, discussed and adopted by the full council.

\section{Research Methodology}

A qualitative approach was used to study the assessment of the role of council committees to exercise financial accountability. The qualitative approach was considered relevant by its ability to undertake the study due to its ability to facilitate flexible, rigorous exploration and engagement with phenomena as they "unfold in real-world situations" (Durrheim, 1999:43). A case study was used to bring clarity and understanding of the role of the council committees. Therefore, the rationale for this approach was informed by the work of Creswell (1994), Yin (1994) and others. The research intended to assess issues related to the functioning of council committees, a case study is considered relevant in "studies that focus on the understanding of areas" that are not well documented (Bryman, 1995). The qualitative method allowed the researcher to adequately evaluate the role that the municipal council and its respective committees played in ensuring and promoting financial accountability. Consequently, the use of the qualitative methodology enabled the researcher to observe the operations of the municipal council committees in their own setting.

The triangulation methodology or multiple sources methods was used to enhance the validity, reliability and the objectivity of the findings and recommendations. In order to achieve the objectives, the research data was collected from multiple sources. The data was collected from primary and secondary sources. Primary data was sourced from members of relevant council committees through structured and unstructured interviews. The questionnaire was the major data collection instrument used to guide the interviews. The interviews were held with portfolio chairpersons and members of the committee. Secondary data was obtained from relevant municipal reports, internet sources, government department publications, journals and Auditor-General's reports. The purposive sampling technique, also called judgment sampling, was the deliberate choice of a participant due to the qualities the participant possesses (Sheppard, 2006). Furthermore, it involves identification and selection of individuals or groups of individuals that are proficient and well-informed with a phenomenon of interest. Accordingly, candidates for the interviews were selected from a list of councillors who served on two committees namely; Oversight Committee, and Audit Committee of Stellenbosch Local Municipality. This method of selecting the respondents was used mainly for convenience as councillors were busy campaigning for the local government elections of 18 May 2011. The Sample size was approximately 37 participants and comprises of committee members and councilors (See Figure 2).

\section{Findings and Discussion}

The research findings identified five significant areas namely: municipality governance environment, authority, procedures used by council committees, capacity and attitudes of council committees in exercising their financial accountability.

\section{Municipality Governance Environment}

A significant finding highlighted that the constant change of the executive structures of the Stellenbosch Municipality created political leadership instability which impact on the general governance environment. Inevitably, committees such as oversight committees were affected negatively. For example, by the time the oversight committee considers the annual report, the executive structures, mainly, the Executive Mayor and the Mayoral Committee had changed. Meaning that, the parties and individuals who were initially in the executive during the financial year under the review were no longer part of the executive. The roles were now reversed and the current committee members now have to assess an annual report for a period when they were the executive in charge. Therefore, the issue of accountability or answerability was merely to comply with the law rather than conducted to hold the executive accountable. Equally, the hostile relationship between parties impacted on the council-executive relations. Good governance principles such as openness, transparency and accountability were replaced by distrust which impacted on access to information and cooperation between parties. In the process decision-making was along party lines and committees lost sight of their responsibility and accountability ultimately suffers. 


\section{Authority}

Several participants raised the issue of authority during interviews. This was linked to the fact that authority was not formally delegated to the oversight committee. Neither was the terms of reference clearly defined. As a result, the oversight committee members were unclear about the authority with regard to key factors such as conducting independent analysis, the power to summon people to appear before the committee or the power to force people to provide additional information. The respondents also highlighted that the authority delegated to council committees was not effective in changing the practice and culture of executive structures' dominance on the budget process. The findings supported an assertion that effective budget accountability will require council committees to exercise scrutiny and oversight on all the stages of the budget process. According to the respondents' experience, the authority of the oversight committee is limited and is confined to compiling an oversight report. This restriction in scope of responsibility negates the committee effective contribution to financial accountability.

\section{Procedures by council committees}

The respondents held that the oversight committee is useful in as far as producing an oversight report on the municipality's annual report. However, highlighted a concern that members of the oversight committee do not attach seriousness to the oversight report. This is mainly due to the fact that the report does not informed policy decision making. The report it appears is mostly compiled for compliance sake and not necessarily to make any meaningful changes in the operations of the municipality. The fact that many committee members were not aware of the main issues reflected in section 71 reports presented to the Council by the Mayor highlighted a challenge in exercising continuous monitoring of the budget process. With regard to the audit committee there is clear structure, processes and procedures with regard to their role. Unlike the oversight committee, the audit committee had a clear agenda and focus. Furthermore, the fact that this committee is independent consisting of external professionals enhance the credibility, role and functions thereof. In the absence of the clearly formulated delegation or Rules of Order, it was unclear as to when and how the council committees were required to meet. It is therefore impossible to make an opinion on the effectiveness of the meetings of the two committees.

\section{Capacity}

The majority of respondents raised an issue of lack of technical capacity and expertise which is not considered as a requirement for appointment. This is the reason most oversight committee members indicated that a lack of technical capacity is a major impediment in their quest to do justice in terms of what is expected of them. In the same vein, the non-executive councillors indicated that a lack of time and accurate information on budget related matters does impact on their effectiveness. In addition, the regulated interaction between councillors and the administration made the task of getting clarity of financial issues more difficult. Also the hostile environment that existed in the municipality made interaction between councillors and official difficult and limited.

\section{Attitude of Council Committees in Exercising their Financial Accountability}

The participants indicated that the oversight committee members are part of a highly political divided council. Therefore, they of the view that Political decision making is not informed by rationality but rather by party political mandate. This has resulted in committee members being partisan in practice. The end result is that accountability is compromised. Another major finding is the general view that the council does not value recommendations regarding financial accountability. As a result, those who are aware of financial irregulaties in the municipality prefer to report them to external law enforcement agencies such as the police rather than first discussing it in the municipal council. This in essence means that the internal system of accountability is not trusted and more trust is placed in outside agencies to call the executive to account.

\section{Recommendations}

The municipal council role should encourage a culture of governance that promotes accountability, openness and transparency. Against this background the municipal council should entrench accountability, openness and transparency through its Rules of Order. Practices that compromise these principles must be discouraged and were if possible the municipal council should take an action against offending parties. Furthermore, financial accountability must be exercise throughout the year and not a once-off activity as is currently the situation. The council committees cannot exercise effective financial accountability only at the tail-end of the budget process. The municipal council committees must participate in all the stages of the budget process. Active involvement in 
all the stages of the budget process will ensure that the council committees are not disadvantaged and dominated by the executive structures who are much more informed about the budget issues than non-executive councillors. Accordingly, the municipal council needs to assign the required authority such as access to information, the power to summon people to the committees and more important the power to demand that their recommendations be implemented by the municipal council. Lastly, oversight committee members must be trained in financial analysis and management as well as additional administrative support be provided to assist in complex financial matters. Council committees require these skills to develop an informed and meaningful input on the financial management process of the municipality.

\section{Conclusion}

The significance of legislative structures such as the municipal councils are an undisputed requirement for effective financial accountability. In addition to other critical roles and responsibilities, municipal council are required to be the custodian of public resources at local government level and that they need to provide leadership on the stewardship of these resources. More importantly, it is the role and responsibilities of council committees to enhance the council oversight ability to hold the executive and the administrative structures to account. Similarly, the article revealed that a mere existence of the committees is not a guarantee that there will be effective financial accountability. Therefore, it is important that the council committees should continuously exercise effective financial accountability not only at the tail-end of the budget process.

\section{References}

Ahmed, N. (2001). "Development and Working of Parliaments in South Asia". Asian Journal of Political Science, 9: 18-48.

Arkava, M. I \& Lane, T.A. 1983. Beginning Social Work Research. Boston: Allyn and Bacon.

Auditor-General. 2008. Financial Statements and Performance Information of Stellenbosch Municipality for the year ended 30 June 2008.

Babbie, E. \& Mouton, J. (2001). The practice of social research. Cape Town: Oxford University Press.

Bless, C. \& Higson-Smith, C. (1995). Fundamentals of Social Research Methods. An African Perspective. 2nd edition. Kenwyn: Juta \& Co.

Brinkerhoff, D. (2001). Taking Account of Accountability. A Conceptual Overview and Strategies Options. Washington DC: World Bank Institute.

Community Law Centre. (2008). Paper II: Municipal Accountability: Assessing Municipal Accountability Tool. University of the Western Cape (April 2008) Available at: www.communitylawcentre.org.za [Accessed 15 March 2011\}.

Creswell, J. W. (2014). Research design: qualitative, quantitative, and mixed methods approaches. 4th ed. Thousand Oaks, California: SAGE Publications.

Dye, K and Stepenhurts, R. (1998). Pillars of Integrity: Importance of Supreme Audit Institutions in curbing Corruption. Washington, D.C World Bank Institute.

Durrheim, K. (1999b). Research design. In M. Terre Blanche \& K. Durrheim (Eds.), Research in practice: Applied methods for the social sciences (pp. 29-53). Cape Town, SA: University of Cape Town Press.

Etzioni, E. (2001). Value for Money Audit in the public Sector. The Nigerian Accountant. Journal of the Institute of Charted Accountants of Nigeria. 34(4): pp.30-31.

Griffith, G. (2005). Parliament and Accountability; The Role of Parliamentary Oversight Committees.

Greenstein, Fred I., and Nelson W. Polsby. (1975) Handbook of Political Science. Volume 5: Governmental Institutions and Processes. Reading, Massachusetts: Addison-Wesley, pp 36.

Gutto S, Soncga Z \& Mothoagae M. (2007). A study on enhancing the status, role, image and positioning of the Parliament of the Republic of South Africa. University of South Africa. Pretoria.

Krafchik, W. \& Wehner, J. (1998). The Role of Parliament in the Budget Process: South African Journal of Economics 66(4):512-541.

Jabbra, G and Dwivedi, P. (1989). Public Service Accountability: A Comparative Perspective. West Hartford, CT: Kumarian Press.

Jibo, M. (2000). The Executive and Legislature; The Theory and Practice of the Separation of Powers. Journal of Political Science. 11 (11), 1-4.

Rabrenovic, A. (2009). Financial Accountability as a Condition for EU Membership; Institute of Comparative 
Law. pp 3048 .

Republic of South Africa: (1996): Constitution (Act 108 of 1996). Pretoria: Government Printers.

Republic of South Africa: (1998): Local Government: Municipal Structures (Act 117 of 1998). Pretoria:

Government Printers.

Republic of South Africa. (2000). Local Government: Municipal Systems (Act 32 of 2000). Pretoria: Government Printers.

Redlynch, S. (2001). Holding to Account. The Review of Audit and Accountability for Central Government. Available at: www.hm-treasury.gov.uk [Accessed 2 February 2011]

Sahgal, V. (2001). The Importance of Quality Parliamentary Oversight: A Global Overview (November). Washington DC., USA Mattson.

Scott, C. (2000). Accountability in the Regulatory State. Journal of Law and Society. Vol. 27, No. 1, Voices, spaces and process in Constitutionalism. pp 38-60.

Santiso, C. \& Belgrano, A.G., (2004). Legislative Budget Oversight in Presidential Systems: Governance of the Budget in Peru. The XVI Regional Seminar on Fiscal Policy. Chile 26-29 January 2004. [Online].

Available at: www.eclac.org/ilpes/noticias/paginas/6/13526/CarlosSantiso.ppt

(Accessed 15 May 2011).

Strom, K. (1998). Parliamentary Committees in European Democracies. Journal of Legislative Studies, 4 (1), 96.

Stapenhurst, R., (2004). Parliamentary Strengthening: The Case of Ghana. World Bank Institute Capacity Building Brief 8.

Sheppard, J. M., \& Young, W. B. (2006). Agility literature review: Classifications, training and testing. Journal of Sports Sciences, 24, 919-932. http://dx.doi.org/10.1080/02640410500457109

2009a. Annual Report for the 2009/ 2010 Financial Year. Stellenbosch: Stellenbosch Municipality.

2009b. Integrated Development Plan, 2 nd Generation, Original Draft. Stellenbosch: Stellenbosch Municipality. 2009c. Annual Budget for the 2009/2010 Financial Year. Stellenbosch: Stellenbosch Municipality.

Wehner, J., (2004). "Effective Financial Scrutiny: The Role of Parliament in Public Finance.” Washington, DC: World Bank Institute.

Yin, R.B. (2003). Case Study Research: Design and Methods. 3rd ed. Newbury Park: Sage Publications.

Fundiswa T Khaile is a lecturer in Public Policy and Administration at the University of the Western Cape, South Africa. She is currently a Ph.D. candidate and holds a Masters in Public Administration (MPA) 2012 , BA. Honours Development Studies 2007, BA 2005 (UWC). She was a visiting scholar at University of Missouri Kansas City (UMKC). She has presented papers in International and local conferences. Her research interest is public policy, public administration and local government.

Gregory J Davids born in Cape Town, South Africa- currently a lecturer at the University Western Cape, South Africa. He is a Harvard- South African Fellow, studied at the International Institute Administratio Publica(IIAP) -France. He was a visiting scholar to University Timisoara- Romania. He assisted local government in policy formulation. His field of study is Public Policy and Governance. He served as a non-executive board member of State Own Entities and chairperson of a non-government organisation. 